\title{
Ideas of experimental pedagogy and pedagogical psychology in Russia and Kazakhstan
}

\author{
Aleksey Alekseyevich Romanov ${ }^{11}$ and Marina Alekseevna Zakharishcheva ${ }^{2}$ \\ ${ }^{1}$ Academy of the FPS of Russia, Department of Legal Psychology and Pedagogy, Ryazan, Russia \\ ${ }^{2}$ Glazov State Pedagogical Institute named after V.G. Korolenko, Department of Pedagogy and \\ Psychology, Glazov, Russia
}

\begin{abstract}
The article draws attention to the sphere of historical and pedagogical knowledge. Being a product of the development of human society, it lies at the core of contemporary and future pedagogical culture. The mature conventional wisdom helps people to forge their own path in the modern world, to determine their self-identification and the prospects for their personal growth. The historical heritage of the first half of the $20^{\text {th }}$ century, rich in invariant ideas, scientific and pedagogical experience, is viewed here by means of its inclusion in the construction of all spheres of life in modern Russia and Kazakhstan, including the development of pedagogy and psychology. The article reveals the stages of scientific activity of the outstanding teacher and psychologist A.P. Nechaev, characterizing the main milestones and dynamics of the formation of domestic experimental pedagogy at the beginning of the $20^{\text {th }}$ century. It highlights the scholar's ideas about syndromic psychology, holistic, mental and moral development of the personality, which are relevant even today. The research is based on conceptual ideas of dialogical pedagogy, problem-personalistic approach, retrospective, comparative historical and historical-phenomenological methods. Experimental pedagogy as a phenomenon of the early $20^{\text {th }}$ century ceased to exist without quite exhausting its capabilities, but it laid the foundation for and determined the strategic development direction of child psychology, pedagogical psychology, genetic psychology, childhood ethnography, differential psychology and differential psychophysiology, and the experiment became a sturdy part of the scholarly apparatus of pedagogy and psychology. The potential of experimental pedagogy made it possible to pose and solve large-scale issues of creating a new school, scientific and pedagogical centers, finding solutions to a wide range of psychological and pedagogical problems, designing research schools that develop natural science, psychological and pedagogical problems of education and upbringing. The invariant ideas of this direction of moral, mental and intellectual development of students are also relevant at the beginning of the $21^{\text {st }}$ century and can be used in the practice of contemporary school education.
\end{abstract}

\footnotetext{
${ }^{1}$ Corresponding author: a.a.romanov54@gmail.com
} 
Keywords: historical consciousness, pedagogical psychology, pedagogical heritage, experimental pedagogy, syndromic psychology

\section{Introduction}

At the beginning of the $21^{\text {st }}$ century, Russia, strengthening its statehood and identity, is taking significant steps to develop integrative ties with the educational systems of Europe and Asia. This, in particular, demonstrates the success of the stable development of our fatherland in the modern world order. Of particular importance is the expansion of Russia's participation in educational processes taking place today in Eurasia. The utilization of the experience in the development of invariant ideas in the field of psychological and pedagogical knowledge accumulated over decades of effort in the republics of the former Soviet Union can be presented as one of the key problems.

We examine the historical processes of the development of pedagogy and psychology in the first half of the $20^{\text {th }}$ century through the lens of their possible inclusion in the construction of all spheres of life in modern Kazakhstan. As an ideological backbone of the development of the Republic of Kazakhstan, we take the main ideas from the article by N.A. Nazarbayev "Looking into the future: modernization of public awareness". It sets out the task of changing public awareness, which would allow a united nation to move into the future, but at the same time, it is important not to lose the legacy of the past, the foundations of its culture, to use the best traditions as a prerequisite for modernization. In the new era, only highly educated people are capable of creating, therefore, the cult of knowledge and education is so necessary. Education, according to N.A. Nazarbayev, is the most fundamental factor of success in the future, it should become number one in the system of youth priorities [1].

In the educational component, we single out the history of pedagogical ideas, as it is important to study them not only for modern upbringing practice, but also for predicting the development of educational systems. The idea as a kind of an ideal construct is a means of human comprehension of reality, it corresponds to the specific goals of social activity and the possibilities of its implementation [2]. The history of pedagogy makes it possible to search for such ideas in the heritage of outstanding scholars.

Articles about famous academic figures of the past raise the problem of the relevance of their ideas, the need to reassess existing points of view. This perfectly applies to A.P. Nechaev whose legacy of the first half of the $20^{\text {th }}$ century still remains relevant and interesting for research at the present time. Much less has been written about this outstanding scholar than he really deserves. Let us highlight a few monographs "Pedagogical Devotees in the Turning Points of the $20^{\text {th }}$ Century" [3], "In the Light of the Invisible: the Life and Fate of A.A. Krogius" [4] and articles "А.П. Нечаевтың ресей мен Қазақстандағы ғылыми-педагогикалық IC-Әрекеті: Туғанына 150 жыл толуына орай” ("Scientific activity of A.P. Nechaev in Russia and Kazakhstan (to the $150^{\text {th }}$ anniversary of his birth") [5], "Aleksander Petrovich Nechaev as a psychotechnician" [6]. Natural science ideas of I.P. Pavlov are also important for us, since they served as expanded basis not only for A.P. Nechaev, but for many domestic and foreign scientists $[3,7,8]$.

Our research is based on the statement that there is a continuity of invariant pedagogical ideas and phenomena which do not lose their meaning and significance over different historical epochs. If the period under study demonstrates relevance, continuity of axiological ideas, rich scientific and pedagogical experience, then this heritage can be used both to solve the problems of upbringing and education in Eurasian countries, and to predict 
the ways of their possible development in the future. The main tasks of the study are to clarify the mechanisms of interaction between experimental pedagogy of the early $20^{\text {th }}$ century and the advanced science and general practice of educational work of that time, as well as to present experimental pedagogy as an integral part of the objective process of the development of pedagogy and pedagogical psychology.

\section{Methods}

The study is based on the conceptual ideas of dialogical pedagogy, where dialogue and dialogics are considered as values of pedagogical theory and practice, without which it is impossible to organize educational space and development of individuals $[9,10]$. The work takes a problem-personalistic approach, which allows "to identify the role of a single individual in solving certain problems of pedagogy in a specific period of its development, to present the image of a teacher, psychologist or educator in a holistic form" [3]. Let us point out the employment of the retrospective method, which makes it possible to study the period of the early 20th century from the point of view of the dynamics of its development and continuity. Let us also highlight the comparative-historical and historical-phenomenological methods, which help to compare historical phenomena synchronously and diachronously within one region and beyond.

\section{$3 \quad$ Results}

At the beginning of the 20th century, the main vectors of the development of pedagogical science were concentrated around the problem of a person. It was required to find objective patterns of the formative influence on the personality, means for solving educational problems, to determine the essential aspects of human development. In order to test the effectiveness of school education and study the nature of a child, teachers and psychologists began to actively employ the experiment method.

The efforts of pedology, psychology, pedagogy, hygiene, physiology, psychiatry were focused around the study of a child. As a result of the cooperation of scientific disciplines, there emerges the phenomenon of experimental pedagogy. The new pedagogical trend combined studies in which the facts of children's development were explained with the help of special observations and experiments, thereby assuming statistical processing of the results, which was supposed to bring pedagogy into the category of exact sciences [3]. A.P. Nechaev became the actual standard-bearer of experimental pedagogy.

Experimental pedagogy was getting public recognition mainly through the organization of all-Russian congresses, which contributed to promotion of new ideas and coordination of experimental work throughout the country. In total, in the pre-October period, 6 congresses were held, commonly referred to as psychological in the literature. Of these, the first two were known as congresses on pedagogical psychology, the next four as congresses on experimental pedagogy, the last one (4th congress on experimental pedagogy) was not mentioned in pedagogical and psychological reference books of the Soviet period.

Supporters of experimental pedagogy opened the first Pedagogical Academy in the country, which embodied K. D. Ushinsky's idea about the comprehensive scientific study of a child and the process of education. Classes there began in the fall of 1908. The task was to professionally train teachers who would have a wide pedagogical outlook, who would know not only their subject, but also the history of education, and who would understand 
their pupils' character. In 1909, on the initiative of A.P. Nechaev, the Society for Experimental Pedagogy was founded.

Scientists of experimental pedagogy sought to introduce scientific expertise on the development of students into the practice of schools at the beginning of the 20th century. Therefore, there was a search for options for changing the content of education, the organization of the learning process itself, the attitude of schoolchildren to learning, as they had to acquire the habit to respect knowledge, understand the value of science, and love meaningful mental work. At the same time, attention was drawn to the fact that one should not be confined only to the problems of education; in the development of the personality, upbringing plays an equally important role when understood as the leading factor in the formation of a morally estimable personality. The purpose of education was the formation of morality, conscience, striving for constant self-improvement.

Along with upbringing, the influence of heredity and environment is no less important in the formation of a personality. Heredity can interfere with education, but it can also contribute to pedagogical success. According to A.P. Nechaev, every effort must be made to understand not only the weak points, but also the strengths of the psyche of the pupil. Upbringing must be built on the strong, morally healthy sides of the mental character of children.

Particular attention should be paid to creating a child-friendly environment in the process of upbringing. The atmosphere of pedagogical tact and kindness should supplant any possibility of children's fears, as the latter are the main means of diverting the attention of schoolchildren from their studies. By their behavior and manner, the teacher either creates an atmosphere for attentive work, or suppresses the students, preventing the child from concentrating on the work or showing interest.

After the October Revolution of 1917, the whole complex of events associated with the formation of psychology on Marxist standpoint turned the forward movement of experimental pedagogy to a dead end, stopping its development as a fascinating scientific phenomenon (the Pedagogical Academy and the experimental school were closed, the work of the Russian Society for Experimental Pedagogy was interrupted).

In 1935, A.P. Nechaev was arrested and exiled to the city of Semipalatinsk (Kazakhstan), where he was the scientific director of the regional institute of physical methods of treatment, a consultant to a psychiatric hospital, a children's outpatient clinic, a sanatorium for neurotic children, a methodologist and director of a health education house, and since 1944, professor of psychology and head of the pedagogy department of the pedagogical institute.

In Semipalatinsk, A.P. Nechaev continued his research aimed at determining the individual differences between people, thereby founding a scientific trend which he called "syndromic" psychology, later to come into scientific use under the name of differential psychology and differential psychophysiology.

A.P. Nechaev made an attempt to find a new approach to solving problems of connection between various psychical and physiological processes of the integral personality of a person, thereby advancing the problems of physiological psychology quite ahead. Such an approach was the transfer of the concept of "syndrome" into psychology, which denotes a set of signs that accompany a certain morbid state. The naturalness of such a transfer is explained by the fact that various syndromes are constantly observed in the psychical realm. Complex psychical states are always characterized by a number of inextricably linked signs, that is, a certain syndrome.

According to A.P. Nechaev, from the point of view of syndromic psychophysiology, mental processes with their physiological basis, which are part of a certain basic syndrome, 
are considered as the biological basis of a personality. This basis, for all its comparative stability, is at the same time subject to the general laws of change. At different moments of life, different syndromes prevail, and as a result, the same personality at different times can be attributed to opposite psychological types. The psychical characteristics of people are determined to a greater extent not by national characteristics, but by the conditions of their life in a certain socio-economic environment [3].

In the last years of his life and creative work, A.P. Nechaev, while working at the pedagogical institute, outlined his plans for experimental work on three topics: "Psychophysiological characteristics of Kazakh children of preschool age, in connection with the general cultural level of their families", "Student essay as a psychological document", "Psychophysiological study of students who are difficult in educational terms".

A.P. Nechaev died and was buried in Semipalatinsk (Kazakhstan) in 1948. The good name of A.P. Nechaev as a scientist and representative of domestic experimental pedagogy was restored in the 90 s of the 20 th century.

\section{Discussion}

In 2002, at the international conference on pedagogical anthropology, academician A.V. Petrovsky, naming outstanding figures in Russian psychology, placed the name of A.P. Nechaev first and foremost. In 2016, at the international conference "Systemic modernization of pedagogical education in the Republic of Kazakhstan: problems, solutions", they talked, in particular, about the legacy of A.P. Nechaev [11]. Let us note a wide-ranging discussion at the international conference "Methodology and practice of the formation of competitive higher pedagogical education" on the problem of overcoming the negative sides of the mental and moral crisis of modern youth. They noted the role of outstanding scientists and educators in the formation of national self-awareness, which is possible only with the support of the formation of historical consciousness, providing understanding of the commonality of tasks in building a new, more perfect state for all its citizens [12].

In the life of modern universities, ideas about the consistent organization of the educational environment, active methods of extracurricular activities of students are actively used [13-16].

\section{Conclusion}

Experimental pedagogy as a scientific trend laid the foundation and determined the strategic direction of development for child and pedagogical psychology, genetic psychology, ethnography of childhood, differential psychology and differential psychophysiology, and the experiment became a sturdy part of the scholarly apparatus of pedagogy and psychology. The potential of experimental pedagogy made it possible to pose and solve large-scale issues of creating a new school, scientific and pedagogical centers, finding solutions to a wide range of psychological and pedagogical problems. At the beginning of the 20th century, the progressive process of strengthening the innovative theoretical and practical foundations of experimental pedagogy contained rich opportunities for the design of research schools that develop natural science, psychological and pedagogical problems of education and upbringing. The invariant ideas of this trend concerning the moral, mental and intellectual development of students are also relevant at 
the beginning of the 21 st century and can be used in the practice of modern school education.

\section{References}

1. N.A. Nazarbaev, Vzglyad v budushchee: modernizatsiya obshchestvennogo soznaniya [Looking into the Future: Modernization of Public Consciousness]. Accessed on: August 04, 2021. [Online]. Available: https://www.akorda.kz/ru/events/akorda_news/press_conferences/statya-glavy-gosudar stva-vzglyad-v-budushchee-modernizaciya-obshchestvennogo-soznaniya

2. G.B. Kornetov (ed.), Pedagogika i obrazovanie v zerkale istoricheskoi refleksii [Pedagogy and Education in the Mirror of Historical Reflection] (ASMO, Moscow, 2015)

3. A.A. Romanov, Pedagogicheskie podvizhniki v perelomnye epokhi XX veka. Izbrannye nauchnye stati i ocherki [Pedagogical Devotees in the Turning Points of the $20^{\text {th }}$ Century. Selected scientific articles and essays] ("Concept" Publishers, Ryazan, 2017)

4. K.S. Maslov, V svete nezrimogo: zhizn i sudba A. A. Krogiusa [In the Light of the Invisible: The Life and Fate of A.A. Krogius] (Tallinn University Publishers, Tallinn, 2014)

5. A.A. Romanov, K.K. Zhampeisova, Bul. Abay Kazakh National Pedag. Univ. Pedag. Sci. Ser. 2(66), 210-216 (2020)

6. N.Yu. Stoyukhina, Psy. Pedag. Search 2(34), 118-128 (2015)

7. D.P. Todes, Ivan Pavlov: A Russian Life in Science (Oxford University Press, New York, 2014)

8. Ivan Pavlov - Biographical. Accessed on: August 04, 2021. [Online]. Available: https://www.nobelprize.org/prizes/medicine/1904/pavlov/biographical/

9. N.A. Astashova, Psy. Pedag. Search 3(47), 15-29 (2018)

10. N.A. Astashova, S.K. Bondyreva, O.V. Malkina, J. Fund. App. Sci. 9(7S), 1392-1418 (2017). https://doi.org/10.4314/jfas.v9i7s.126

11. Sistemnaya modernizatsiya pedagogicheskogo obrazovaniya Respubliki Kazakhstan: problemy, puti resheniya [Systemic modernization of pedagogical education in the Republic of Kazakhstan: problems, solutions], in Proc. international scientific and practical conference (Almaty, 2016)

12. Metodologiya i praktika stanovleniya konkurentosposobnogo vysshego pedagogicheskogo obrazovaniya [Methodology and Practice of the Formation of Competitive Higher Pedagogical Education], in Proc. international scientific and practical conference (Abay KNPU, Almaty, 2018)

13. A. Díaz-Iso, A. Eizaguirre, A. García-Olalla, Sustainability, 11(17), 4521 (2019). https://doi.org/10.3390/su11174521

14. I.V. Khairova, V.I. Toktarova, International Journal of Environmental and Science Education, 11(9), 2255-2265 (2016). Accessed on: August 04, 2021. [Online]. Available: https://www.learntechlib.org/p/195200/

15. R. Ju, et al., EURASIA J. Math., Sci and Tech. Edu. 13(8), 5281-5293 (2017). https://doi.org/10.12973/eurasia.2017.01003a 
16. R. Raaper, Teach. Higher Edu. 24(1), 1-16 (2019).

https://doi.org/10.1080/13562517.2018.1456421 